\title{
公共図書館の開架閲覧空間における座席領域特性と平面構成の関係に関する研究 STUDY ON THE RELATIONSHIP BETWEEN SEATED AREA FEATURES AND FLOOR PLAN COMPOSITION OF OPEN READING SPACES IN PUBLIC LIBRARIES IN JAPAN
}

\author{
小島悠暉*1, 小松 尚*2 \\ Yuki KOJIMA and Hisashi KOMATSU
}

\begin{abstract}
This study aims to clarify the relationship between seated area features and floor plan compositions of open reading spaces found in 55 Japanese public libraries completed since 2000. These elements are approached from the viewpoints of floor plan forms, bookshelves area arrangement, seated areas, and seating arrangements in seated areas. In particular, the statistical analyses of 792 seated areas - based on the nature of users' coexistence with the viewpoints of socio-petal, socio-fugal, and side by side - eight types of seat arrangements in seat areas and the relationship between seat arrangement types and floor plan form types can be found.
\end{abstract}

Keywords : Public Library, Open Reading Space, Seated Area, Floor Plan Composition, Coexistence, Seating Arrangement 公共図書館，開架閲覧空間，座席領域，平面構成，共在，座席配置

\section{1. 研究の目的と方法}

\section{1-1. 研究の背景}

公共図書館は図書館法の公布以降、図書や資料の保存から利用、 閉架から開架、閲覧から貸出と、基本モデルを変容させてきた ${ }^{122)}$ 。 そして 1990 年以降には、子供の読書活動支援やビジネス支援など、 多様なサービスを提供しており、幅広い市民の利用を促すサービス や利用者の多目的な滞在を可能とする空間計画が見られるようにな った ${ }^{3) 4}$ 。しかし現在も、管理面や面積効率の高い空間利用の観点 から書架が並び、閲覧席が一様に並べられている事例が見られる。 開架閲覧室の計画論では細かく部屋に区切らず、ワンルームを排架 の利用者属性ごとに家具等を用いて分節化することが重要とされて いる ${ }^{5)}$ 。また、A・ウィッカーは「行動場面はその活動プログラム

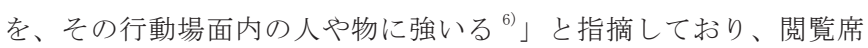
が一様に並べられているような空間では利用者の過ごし方が制限さ れる恐れがある。したがって、多様な過ごし方を許容する公共図書 館を目指寸ために、開架閲覧空間を緩やかに分節していくことが望 ましいと考えられる。よって、現在の公共図書館において開架閲覧 空間がどのように分節され、また分節された領域にはどのように閲 覽席が設えられているかを分析し、その領域構造を明らかにするこ とは、開架閲覽空間の緩やかな分節に関する計画論の構築に向けた 一助になると筆者は考えている。

\section{1-2. 研究の目的}

まず本研究では、公共図書館の開架閲覧空間における書架の集合 体による領域を書架領域、椅子及び机の集合体による領域を座席領 域という、2つの領域を定義する。その上で、本研究は来館者が主 に滞在する座席領域に着目し、(1)開架閲覧空間の平面形状及び書架
領域（以下、平面構成）と座席領域の関係性、(2)座席領域内におけ る座席配置を他者との共在状況注 1 ) から類型化し、その類型と平面 構成の関倸性に関して分析寸る。つまり、座席領域と平面構成を相 互に分析することにより、公共図書館の開架閲覧空間における座席 領域の特性と平面構成の関係性を明らかにし、計画上の知見を示寸 ことを目的とする。

\section{1-3. 研究の方法}

滞在型公共図書館の嚆矢となる事例が 1990 年代から現れ始め、 その頃から滞在型を志向した計画、設計、施工が行われたことを考 慮し、建築系雑誌及び図書館系建築誌である「新建築 ${ }^{7)} 」 「$ 近代建 築 ${ }^{8)}$ 」「建築設計資料 ${ }^{9)} 」 に$ 掲載された公共図書館の内、2000 年〜 2015 年に䇋工した 55 事例の家具レイアウトの入った平面図を収集 し、その主要階注2) を分析対象とする。

まず、55 事例それぞれの主要階における開架閲覧空間の平面形 状と書架領域の配置を類型化し、座席領域の数や規模との関係性を 分析する。次に、55 事例から抽出した全ての座席領域を座席配置 の観点から類型化し、各類型の共在状況に関する分析を行い、さら に、各事例における座席領域の類型構成と平面構成の関係を分析す る。

\section{2. 既往研究と本研究の位置付け}

桂 ${ }^{10)}$ は古代から現代までの図書館を建築的視点から通覽し、共 通する機能的特徵は資料の収蔵であり、時代とともに変容するもの の、独自の場所感覚を生み出していると指摘している。資料を収め る書架とその配置が、図書館固有の場所感覚を生み出していると解 釈できる。植松 ${ }^{1)}$ は平面計画の視点から開架閲覧空間の基本的構
KUME SEKKEI Co. Ltd., M.Arch.

Prof., Graduate School of Environmental Studies, Nagoya Univ., Dr.Eng.

$* 2$ 名古屋大学大学院環境学研究科都市環境学専攻 教授·博士 (工学) 
成を 4 つに分類して説明している。具体的には、(1)壁面の書架が中 央の座席空間を取り囲む形を取る、バロック期に起源をもつ知の殿 堂である図書館建築の定型と言えるギャラリー型、(2)ギャラリー型 の展開形であるが、壁面書架から中央に書架が突き出す形をとるコ ーナー型、(3)現在主流となった部屋の中央に自立型書架が並ぶ書架 ブロック型、(4)書架と座席が渾然一体と配置されたコーナー形成型 である。しかしこの分類も、基本的に書架配置の点から導き出され ており、座席空間についてはその規模や明るさの点について言及さ れるに留まる。

開架閲覧空間の計画に関する先行研究としては、北岡 ${ }^{1112) 13) 14)}$ が 書籍排架の観点から一般書エリアにおけるゾーニング手法を提案し ている。書籍排架によってポピュラーライブラリエリアを創出する 可能性を示し、実際に成人利用やファミリー利用に着目することに より、具体的な開架閲覧空間におけるゾーニングに関する指摘を行 っている。中井ら ${ }^{15) 16(17)}$ は利用者行動に着目して分析し、ワンル 一ムの空間をいかに他の空間と分節化するかが重要であると指摘し ている。また、館内における着座などの利用行動は空間的な特徴や 閲覧室の広さ、各座席の数や向き、書架との位置関係など館内レイ アウトによって変わる可能性を指摘している。しかし、どちらも開 架閲覧空間における空間計画に関する研究ではあるが、座席空間の 具体的な計画に関する指摘は見られない。

よって本研究は、開架閲覧空間に配置された座席領域及びその領 域内の座席配置と、開架閲覧空間の平面構成との関係について考察 し、計画上の知見を得ようとする点に特色があると考えている。

\section{3. 調査対象の基礎的情報}

\section{3-1. 調査対象事例の概要}

調查対象事例である 55 事例の年代に偏りはなく、立地を見ると 商業系と住居系の用途地域に多い (Fig. 1)。延床面積は 2,000 4,000 $\mathrm{m}^{2}$ の事例が多く、次いで 2, $000 \mathrm{~m}^{2}$ 以下の事例が多い。それに 対し、10,000 $\mathrm{m}^{2}$ を超える事例は 2 事例であった。また、主要階の 開架閲覧空間面積をみると、38 事例が $1,000 \sim 2,000 \mathrm{~m}^{2}$ の規模で あり、2,000 $\mathrm{m}^{2}$ 以上の事例は少ない。

\section{3-2. 開架閲覧空間の平面形状と書架領域の分類}

55 事例の開架閲覧空間について、平面構成の概要と傾向把握の ため、平面形状と書架領域の配置を分類する。平面形状は広室型、 外縁部分節型、ヴオイド型、コア型、領域配置型、室群型の $6 つ^{\text {注 }}$ ${ }^{3)}$ 、書架領域の配置の類型（以下、書架領域型）は単一集中型、複

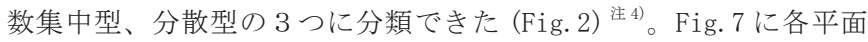
形状の例を示しており、平面形状の類型（以下、平面型）それぞれ の特徵は次の通りである。広室型は一体的な空間に書架と座席を配 置しており、書架領域が閲覧空間を分節している。外縁部分節型は 建物の外縁部を凹凸形とし、閲覧空間を分節している。ヴオイド型 は建物内に吹き抜け空間や中庭を、コア型は管理部門等を建物中央 に配置し、その周囲を閲覧空間としている。領域配置型は壁柱や垂 れ壁といった建築的要素により、閲覧空間内に座席領域や書架領域 を形成している。室群型は武蔵野プレイスの 1 事例のみであるが、 開架閲覧空間としては比較的小規模の単位空間を連結している。

分類した結果、平面型では広室型が 34 事例と最も多く、書架領 域型では単一集中型が 26 事例と最も多い。平面型と書架領域型の

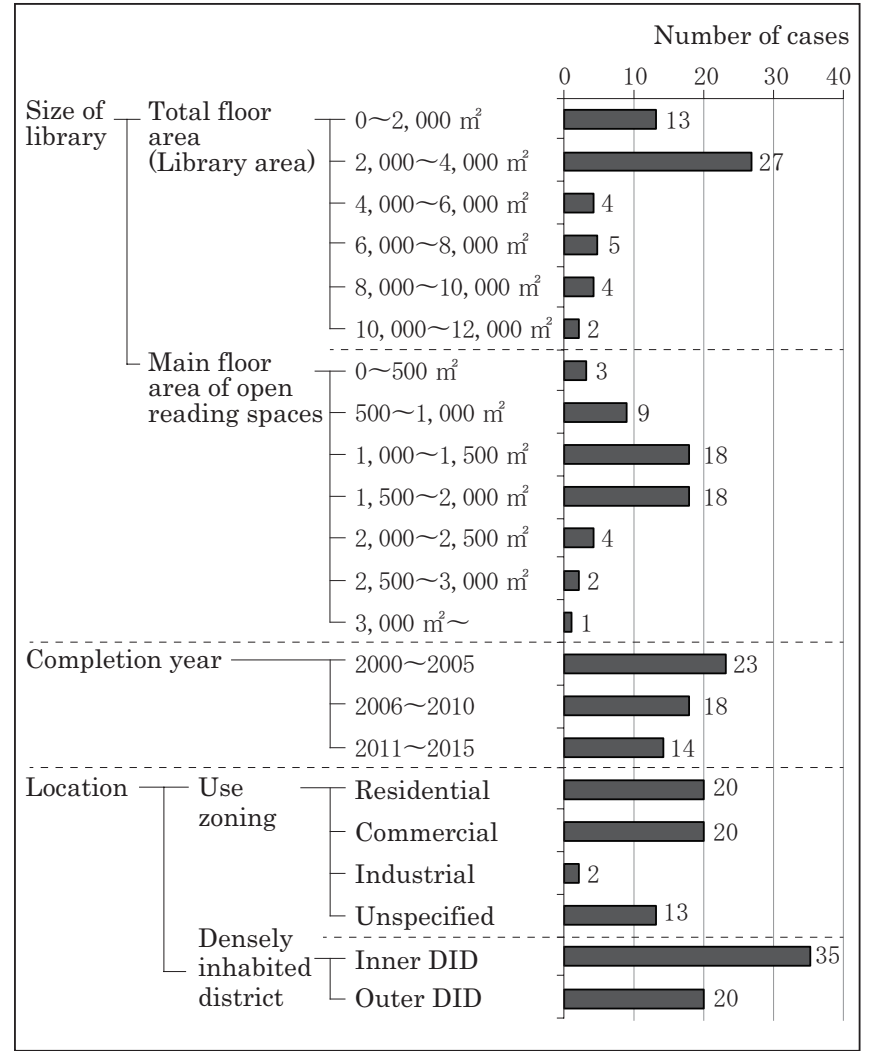

Fig.1 Outline of the survey cases

\begin{tabular}{|l|c|c|}
\hline \multicolumn{3}{|c|}{ Types of floor plan } \\
\hline Large room type (La) & $\begin{array}{c}\text { Outer edge } \\
\text { segmentation type (Ou) }\end{array}$ & Void type (Vo) \\
\hline & & \\
\hline
\end{tabular}

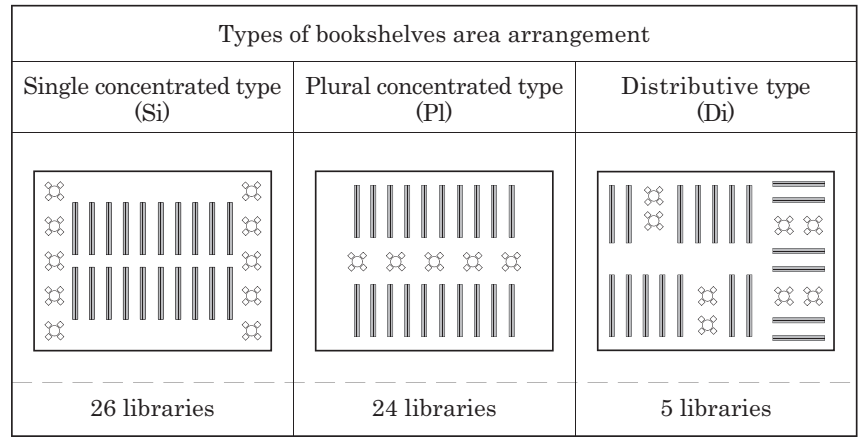

Fig.2 Types of Floor plan and bookshelves area arrangement 


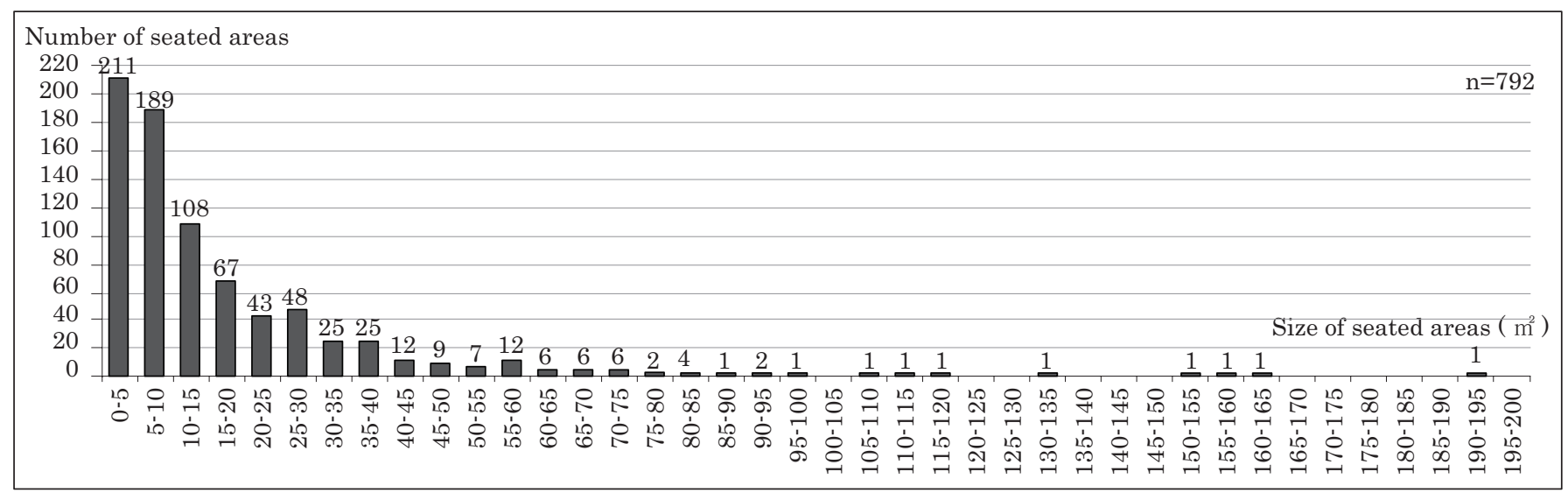

Fig.4 Histogram of seated areas size

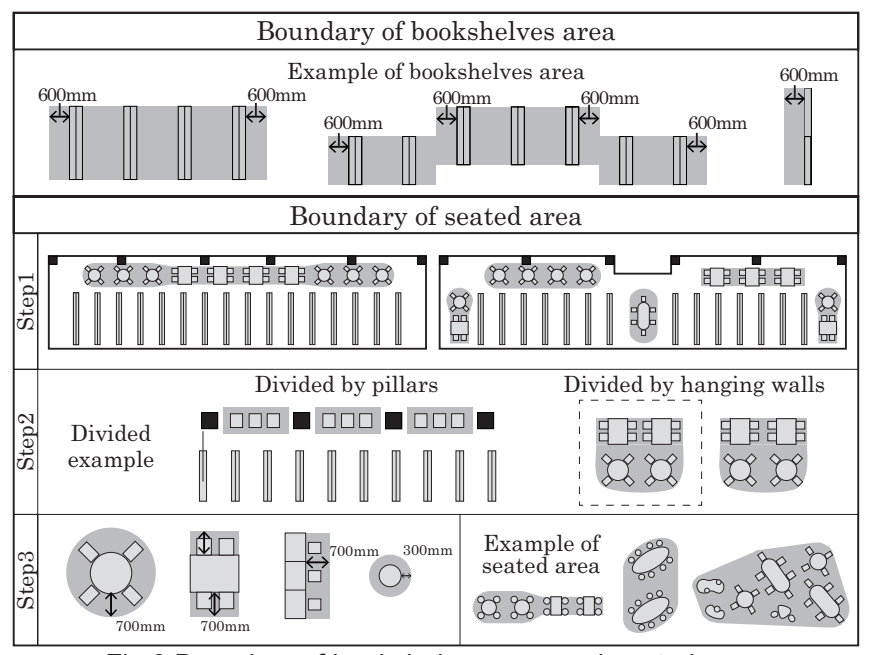

Fig.3 Boundary of bookshelves area and seated areas

組み合わせでは広室型と単一集中型、広室型と複数集中型の組み合 わせがそれぞれ 17 事例、15 事例と多い注5)。

\section{3-3. 書架領域及び座席領域の定義、及び境界の決定方法}

書架領域と座席領域を詳細に分析するために、各領域の定義と境 界の決定方法を示す。まず、書架領域を「利用者が書籍や資料を選 択するための空間を含めた、書架によって構成される領域」と定義 し、その境界の決定方法は次の通りである (Fig. 3)。書架の正面方 向は、一般的な通路幅 ${ }^{3)}$ である $1200 \mathrm{~mm}$ の半分である $600 \mathrm{~mm}$ オフセ ットした位置を領域の境界とし、書架の側面と背面方向は、書架の 位置と領域の境界が一致するものとする。壁面書架も他の書架と同 様に、書架の正面方向に $600 \mathrm{~mm}$ オフセットした位置を領域の境界と した。

次に、座席領域を「書架や建築的な要素によって形成され、椅子 及び机によって構成される領域」と定義し、その座席領域を次のよ うな手順で決定した注6)。まず平面構成を確認しながら、Step 1のよ うに椅子及び机が配置されている空間を座席領域として同定する。 次に、同定した座席領域周辺の柱や垂れ壁等を考慮し、Step1 で同 定した座席領域をさらに細分化するかを判断する。細分化する例を Step2 に示す。柱等に面する領域の半分以上が柱等に隠れている場 合や、垂れ壁等によって空間が分かれていると考えられる場合であ る。

さらに、Step3 として椅子及び机の集合体の形状を考慮して、座 席領域の境界を決定寸る。境界の具体的な決定方法を以下に示寸。

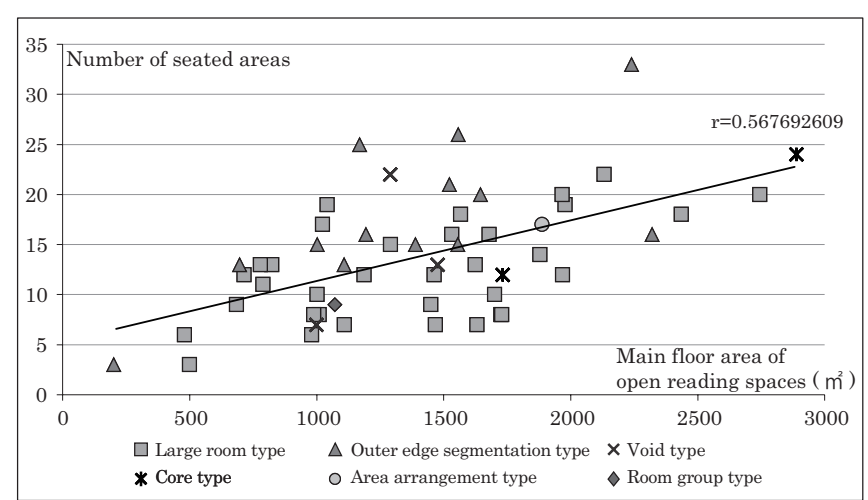

Fig.5 Relationship between floor plan and number of seated areas

・机と椅子がセットの場合は、机から椅子がある方向に $700 \mathrm{~mm}$ オフ セットした位置を境界とする。

・椅子単体の場合は、人が座ることが可能な方向に $300 \mathrm{~mm}$ オフセッ トした位置を境界とする。

・椅子及び机の集合体による座席領域は、各家具の領域の外形線を 結んだものを領域の境界とする。

\section{4. 平面構成と座席領域の関係性 \\ 4-1. 座席領域の面積分布}

全 55 事例の主要階から抽出した 792 個の座席領域の面積分布を みると、0〜 $5 \mathrm{~m}^{2}$ の座席領域が最も多く、領域面積が大きくなるに つれて領域数は減少していき、75 $\mathrm{m}^{2}$ 以上の座席領域はわずかであ った（FIg. 4)。最も大きい座席領域は $194.6 \mathrm{~m}^{2}$ であった。1〜3つ 程度の家具で構成されている $0 \sim 5 \mathrm{~m}^{2}$ の座席領域や $5 \sim 10 \mathrm{~m}^{2}$ の座 席領域などは、ほとんどの図書館で見られた。それに対し、75 $\mathrm{m}^{2}$ 以上の座席領域は、Fig. 7 の主要階平面図を参照すると、コア型で ある掛川市立中央図書館のように閲覧席がまとまって外縁部に配置 されている場合や、岐阜メディアコスモスのように建築的な要素に より規模の大きな座席領域を構成している場合が見られた。

\section{4-2. 開架閲覧空間の面積と座席領域数の関係}

開架閲覧空間面積と座席領域数、及び平面型の関倸性を分析し、 平面形状の影響を考察する。主要階の開架閲覧空間の面積と座席領 域数の相関関係をみると、相関係数 0.567 と弱い正の相関が見られ たが、ばらつきも見られる(Fig. 5)。広室型の事例に注目してみる と、線形近似曲線の值に対してばらつきがみられる。その理由とし て、書架領域の配置による影響が考えられる。つまり、書架によっ 
て座席領域を分節している場合は座席領域数が増え、単一集中型な どの書架がまとまって配置されている事例は座席領域数が少ないと いうことが想定される。詳細は次節以降で分析する。それに対して 外縁部分節型に着目してみると、Fig. 7 の主要階平面図にある愛荘 町愛知川図書館のように、その平面形状が複数の座席領域を生み出 しており、ほとんどの事例で線形近似線の值よりも座席領域数が多 い結果となった。

\section{4-3. 書架領域型と開架閲覧空間の面積の関係}

3 つの書架領域型毎に、主要階における開架閲覧空間の面積を みると、単一集中型の平均值が $1229.5 \mathrm{~m}^{2}$ であり、複数集中型、分 散型の面積と比べて小さく、1,000 1,500 m²の事例が多い（Fig. 6 (1) )。 t 検定の結果、単一集中型と複数集中型には有意差（ $\mathrm{p}<0.05$ ）が確認できた注 7 。また、最大值が $1,800 \mathrm{~m}^{2}$ 以下であり、複数集 中型や分散型の事例と比較して事例の規模にばらつきが少ない。そ れに対し、複数集中型の事例は平均值が $1558.4 \mathrm{~m}^{2}$ であり、分散を 見ると $1,000 \sim 2,000 \mathrm{~m}^{2}$ 事例が多く、ばらつきが見られた。分散 型の事例は平均值が $2606.4 \mathrm{~m}^{2}$ であったが、実際は 2, $000 \mathrm{~m}^{2}$ 前後の 事例が多い。

\section{4-4. 書架領域型と座席領域数の関係}

単一集中型の平均值が 12.2 個、複数集中型の平均值が 14.7 個、 分散型の平均值が 23.8 個となっており、単一集中型とそれぞれの 配置方法の間には有意な傾向（p<0.1）があった。(Fig. 6 (2) )。4-3 で明らかにしたように、開架閲覧空間の面積は書架領域が複数にな り、分散するほど大きくなる傾向にあるが、その傾向と同様に単一 集中型の事例では座席領域数が少なく、複数集中型、分散型の事例 では、領域数が多くなる傾向にあると言える。分散型の事例に着目 すると、Fig. 6 (1)に示しているように、開架閲覧空間の面積は最大 值によって平均值が引き上げられているが、座席領域数はより中央 值に近い值となっている。

\section{4-5. 各書架領域型における座席領域及び書架領域の合計面積割合}

座席領域の合計面積の割合をみると、単一集中型の事例の平均值 が $15.4 \%$ 、複数集中型の事例が $17.6 \%$ 、分散型の事例が $17.4 \%$ と なっており、 $\mathrm{t}$ 検定でも有意差は確認できず、書架領域の配置によ る違いはあまり見られない (Fig. 6 (3))。それに対して、開架閲覧 空間に対する書架領域の合計面積の割合をみると単一集中型は 35 〜 40\%の事例が多く、複数集中型は $30 \sim 35 \%$ 、分散型は $30 \%$ 以 下の事例が多い（Fig. 6 (4)）。また、分散型とそれぞれの配置方法 には有意差（p<0.05）が確認できたことから、書架領域が分散する ほど書架領域割合が減少していると言える。

差が見られた要因として、開架閲覧空間内の動線空間の形状が考 えられる。単一集中型では書架がまとまって配置されているため、 動線空間も比較的単純な形状となり、面積的にも小さくなるため、 書架領域の面積割合が相対的に高くなったと考えられる。これに対 し、分散型では動線空間の形状が単一集中型に比べて複雑になり、 また面積的にも比較的大きくなるため、書架領域の面積割合が相対 的に低くなったと考えられる。

\section{4-6. 平面型及び書架領域型と座席領域の関係}

各事例における座席領域規模、座席領域内における家具数注 8 、 座席領域内における座席領域を構成する座席家具の種類数 (以下、 座席家具の種類数 ) ${ }^{\text {i土 9) }}$ の 3 つの要素によるバブルチャートを作成

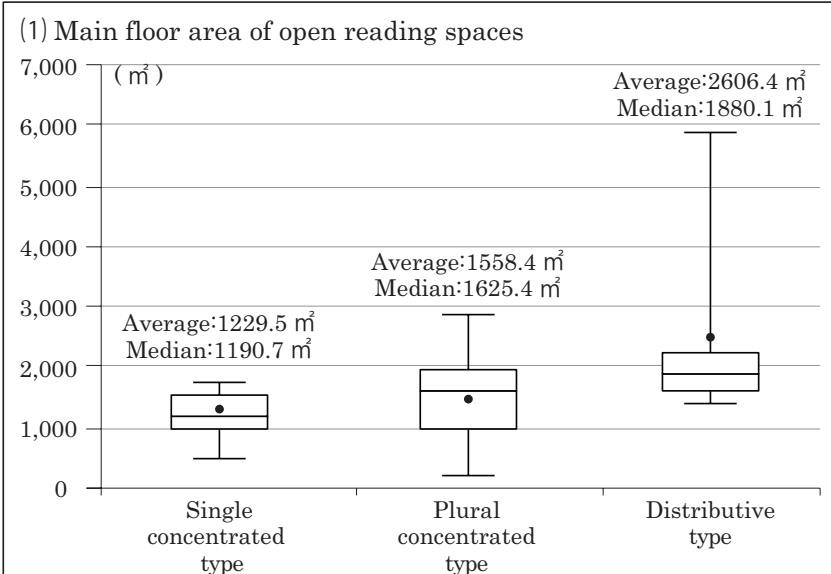

(2) Number of seated areas

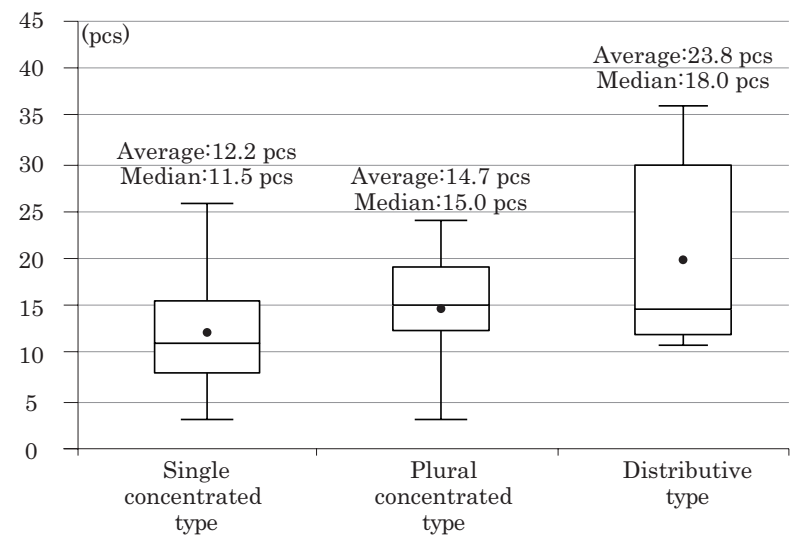

(3) Percentage of seated areas

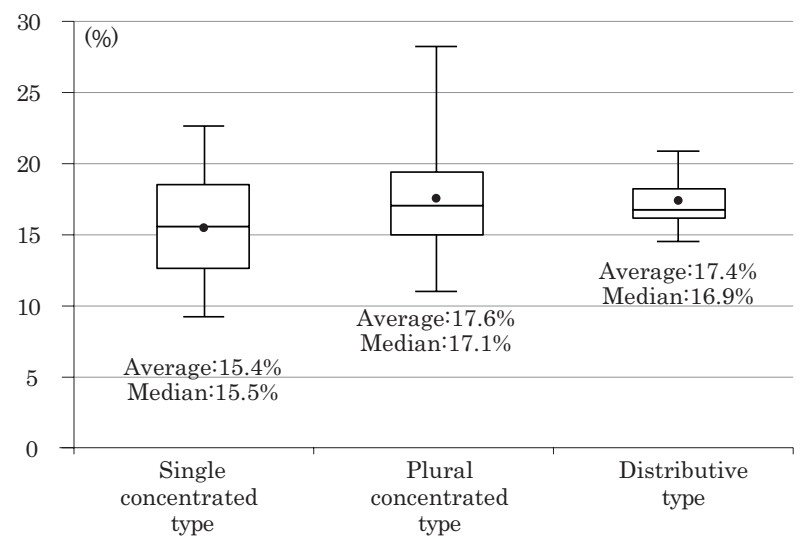

(4) Percentage of bookshelves areas

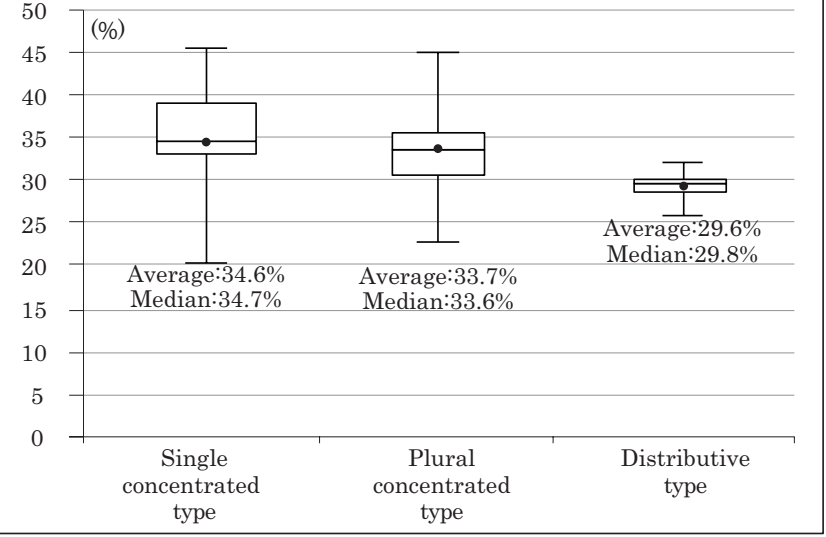

Fig.6 Relationship between bookshelves area arrangement and size of open reading spaces or seated area 


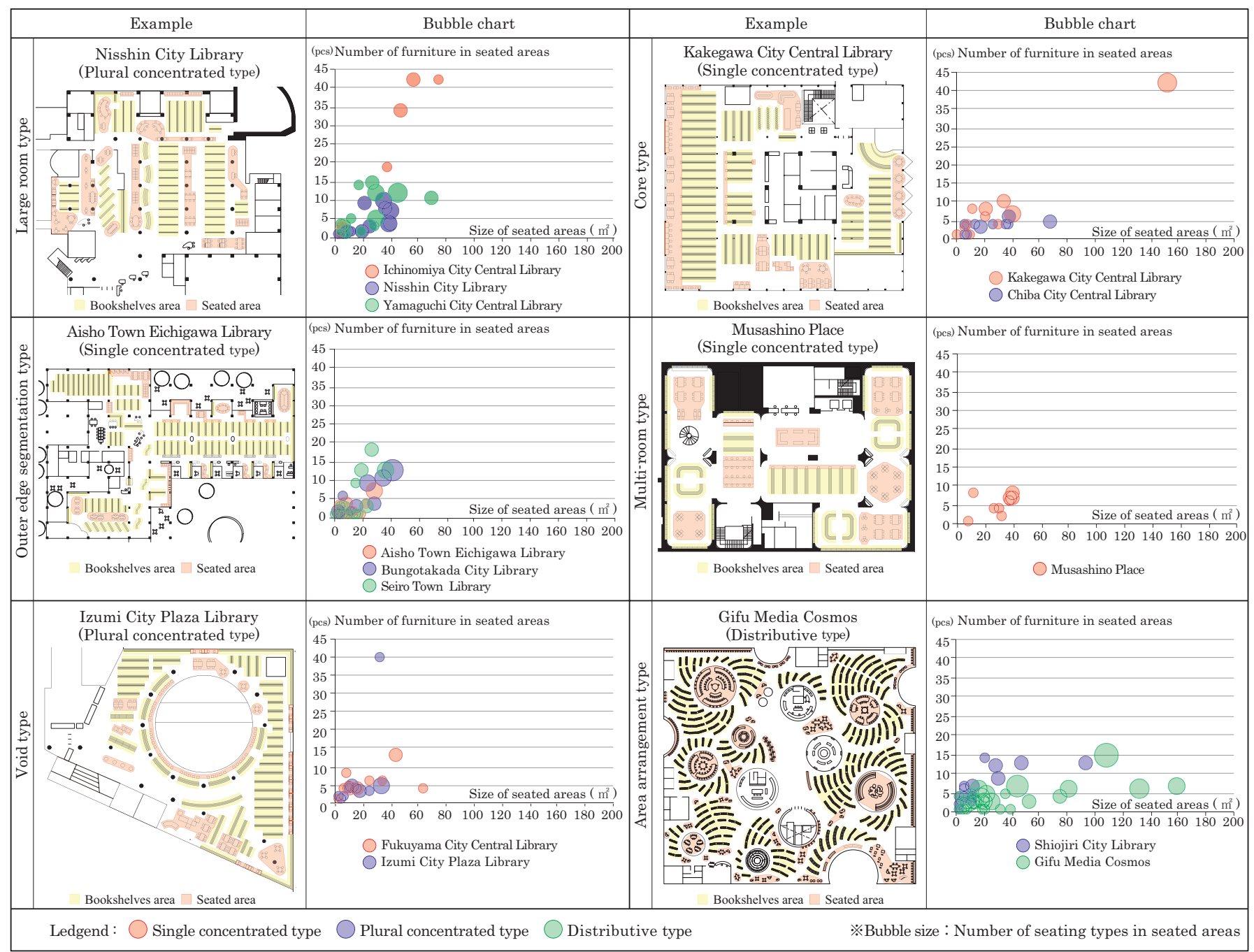

Fig.7 Relationship between floor plan, bookshelves area arrangement, size of seated area and number of furniture in seated area

した（Fig. 7)。これを基に、各平面型における書架領域型毎の各座 席領域の規模と総数の分散度合いを把握し、座席領域の形成上、平 面形状と書架領域のどちらがより強い要因になっているかを分析し た。

広室型とコア型の単一集中型の事例では、外縁部に配置された座 席領域に多数の家具が配置されており、同時に大規模と小規模の領 域が形成されている事例が多い。そのため、各事例における領域規 模に差が生まれていた。それに対し、広室型及びコア型における複 数集中型、分散型の事例では、小中規模の座席領域が形成されてお り、領域規模の差は小さくなる傾向にあった。このことから、広室 型とコア型における座席領域の形成には、書架領域の影響が大きい と考えられる。

外縁部分節型の事例では、建物外縁部の凹凸形の空間に小規模の 座席領域が形成されており、各書架領域型における座席領域の規模 や総数にあまり差が見られない。そのため、座席領域の形成には平 面形状の影響が大きいと考えられる。ヴォイド型は建物外縁部とヴ オイド周辺部に家具が配置されており、ヴオイドの数やスケールに よって、座席領域数や規模が異なる。室群型はその単位空間が座席 領域を規定しているため、領域規模に差が見られない。ヴオイド型 や室群型では書架領域の配置の違いはあまり見られないため、外縁
部分節型と同様に座席領域の形成には平面形状の影響が比較的大き いと考えられる。

領域配置型の 2 事例をみると、塩尻市立図書館における壁柱や、 岐阜メディアコスモスにおけるグローブのように、平面の外形に留 まらない建築的な要素によって形成されている座席領域と、書架領 域の配置に応じて形成されている座席領域がある。

さらに Fig. 7 のバブルの大きさ、すなわち座席家具の種類数に注 目すると、同規模の座席領域でもバブルの大きさが異なるため、平 面型や座席領域の規模等と座席領域内の空間特性には関係性がある 可能性が推察される。しかし、Fig. 7 やこれまでの分析上の視点か らはそれを明らかにできないため、次章以降で座席領域内の座席配 置に着目した分析を行う。

\section{5. 他者との共在状況から見た座席領域内の座席配置構成の特性と 平面構成の関係}

本章では座席領域内の座席配置に注目し、特に他者との共在状況 を考慮した分析を行い、座席領域内の座席配置構成の特性を明らか にする。さらに、その特性と平面構成との関係を分析する。

\section{5-1. 座席配置の基本分類}

公共図書館に設置されている家具の座席配置をオズモンド 
(Osmond, H. ) の提唱した座席配置の分類 ${ }^{18)}$ を用いて整理する (Fig. 8)。本研究では他者と居合わせない個人用の家具はパーソナ ルとし、他者と居合わせることが可能な家具を座席配置の観点から サイドバイサイド、ソシオフーガル、ソシオペタルと分類する。

\section{5-2. 着座可能人数ごとの家具形状と座席配置の細分類}

55 事例より抽出したソシオペタル及びソシオフーガルの着座可 能人数 ${ }^{10)}$ ごとの家具形状を Fig. 9 に示す。家具形状の観点からみ ると、ソシオペタルの家具では 6 人以上の偶数人用が、ソシオフー ガルの家具は少人数用の家具において比較的多様である。

55 事例から抽出した各着座可能人数における家具設置数の分布 をみると、ソシオペタルの座席配置では 4 人用の家具が 422 と最も 多く、 5 人用以上の家具で、偶数人用の家具と奇数人用の家具で数 的な多少があるが、全体的に少なくなっている (Fig. 10)。ソシオ フーガルの座席配置では、奇数人用の家具と偶数人用の家具で多少 は見られるものの、ソシオペタルほど設置数に差異は見られな い。そこで、ソシオペタルの座席配置は他者との居合わせの感覚が 強く、ソシオフーガルの座席配置はプライベート性を確保しやすい という特性と、家具形状の多様性及び家具設置数に関する上記の分 析結果を考慮して、2〜 4 人用の家具を小規模ソシオペタル、5人 用以上の家具を大規模ソシオペタルと細分類し、ソシオフーガルは 細分類しないこととした。

\section{5-3. 座席領域の分類軸の抽出}

前節で細分類した 5 つの座席配置分類（パーソナル、サイドバイ サイド、小規模ソシオペタル、大規模ソシオペタル、ソシオフーガ ル）を基に、全 55 事例から抽出した 792 の座席領域内における各 分類の座席総数を変数として主成分分析 ${ }^{11}$ を行い、 5 つの主成分 を抽出した。その中で、変数として使用した各座席配置分類以上の 情報をもつとみなすことが可能な固有值が 1 以上である主成分 1 3 を採用し（累積寄与率 $66.51 \%$ )、次節以降の分析を行う。

まず、主成分 1 ～ 3 の解橎を以下に示す (Fig. 11)。

(1)主成分 1 : 座席の独立性

パーソナルのみがプラス側に值を示しており、小規模ソシオペタ ルという 4 人掛け閲覧席のように座席が対面し、居合わせの感覚が 強いと考えられる座席配置がマイナス側に高い值を示していること ら、座席の独立性を表すと解䣋できる。

(2)主成分 2 : 着座方向の許容度

主成分 2 ではソシオフーガルや大規模ソシオペタルといった、着 座方向が他の座席配置と比較して、あまり制限されない座席配置が プラス側に值を示し、サイドバイサイドや小規模ソシオペタルとい った他の座席配置より着座方向が限定的な座席配置がマイナス側に 值を示していることから、着座方向の許容度を表すと解釈できる。 この着座方向の許容度とは、1つの家具における利用者の座る方向 の自由度とも言える。具体的には、ソシオフーガルの座席配置では 他者の着座方向を考慮して、利用者自身がある程度着座方向を選択 できるため、着座方向の許容度が比較的高いと考えられる。それに 対し、サイドバイサイドの座席配置では利用者が同じ方向を向くた め、着座方向の許容度は比較的低いと考えられる。

(3)主成分 3 : 他者との共在時における座席の選択性

主成分 3 では、大規模ソシオペタルやサイドバイサイドといった 同質の座席が並ぶ座席配置がプラス側に值を示し、小規模ソシオぺ

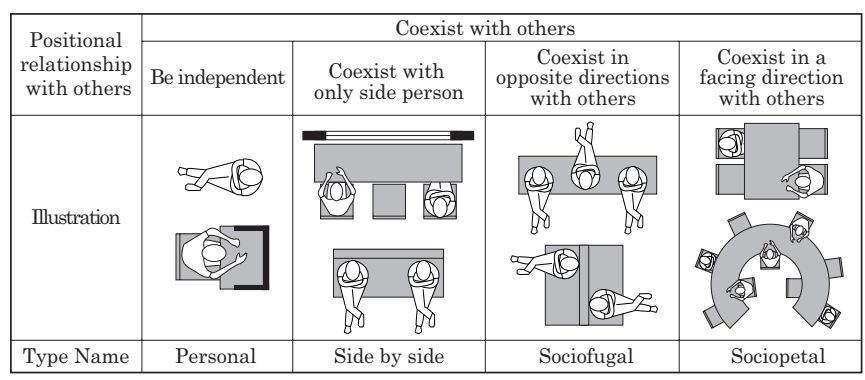

Fig.8 Basic classification of seating arrangement

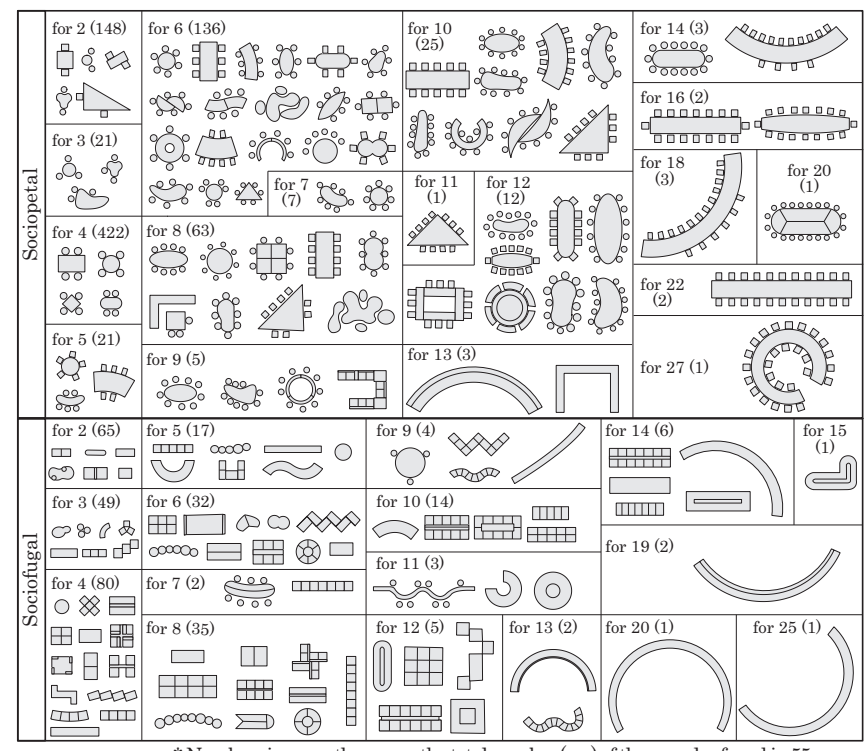

${ }^{*}$ Numbers in parentheses are the total number (pcs) of the samples fo
Fig.9 Furniture shapes for each seating capacity

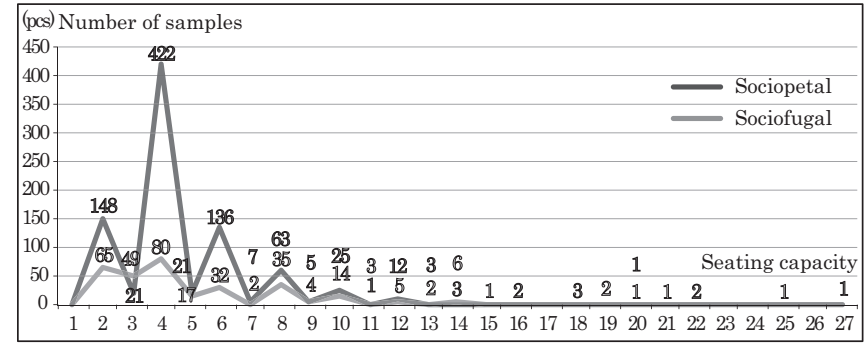

Fig.10 Distribution of the number of the samples for each seating arrangement

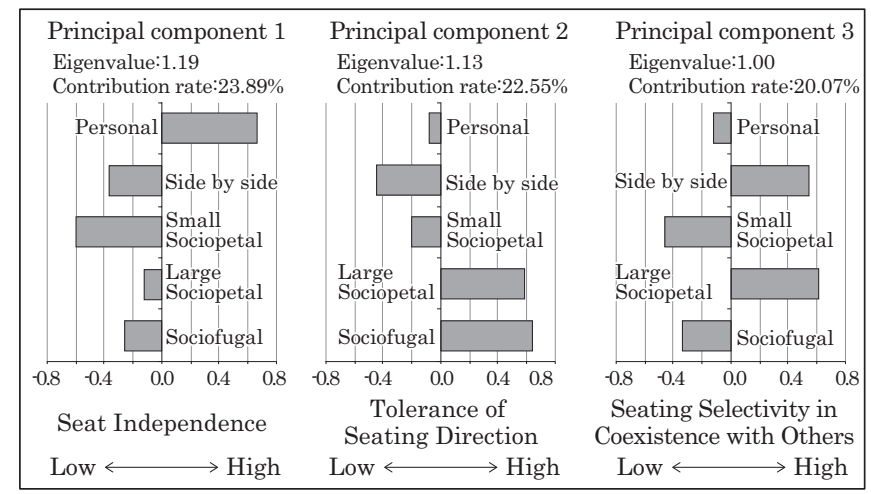

Fig.11 Result of principal component analysis

タルやソシオフーガルといった他者の存在が座席選択に強く影響を 与えると考えられる座席配置がマイナス側に值を示していることか ら、他者との共在時における座席の選択性を表すと解釈できる。こ の他者との共在時における座席の選択性とは、1つの家具において 


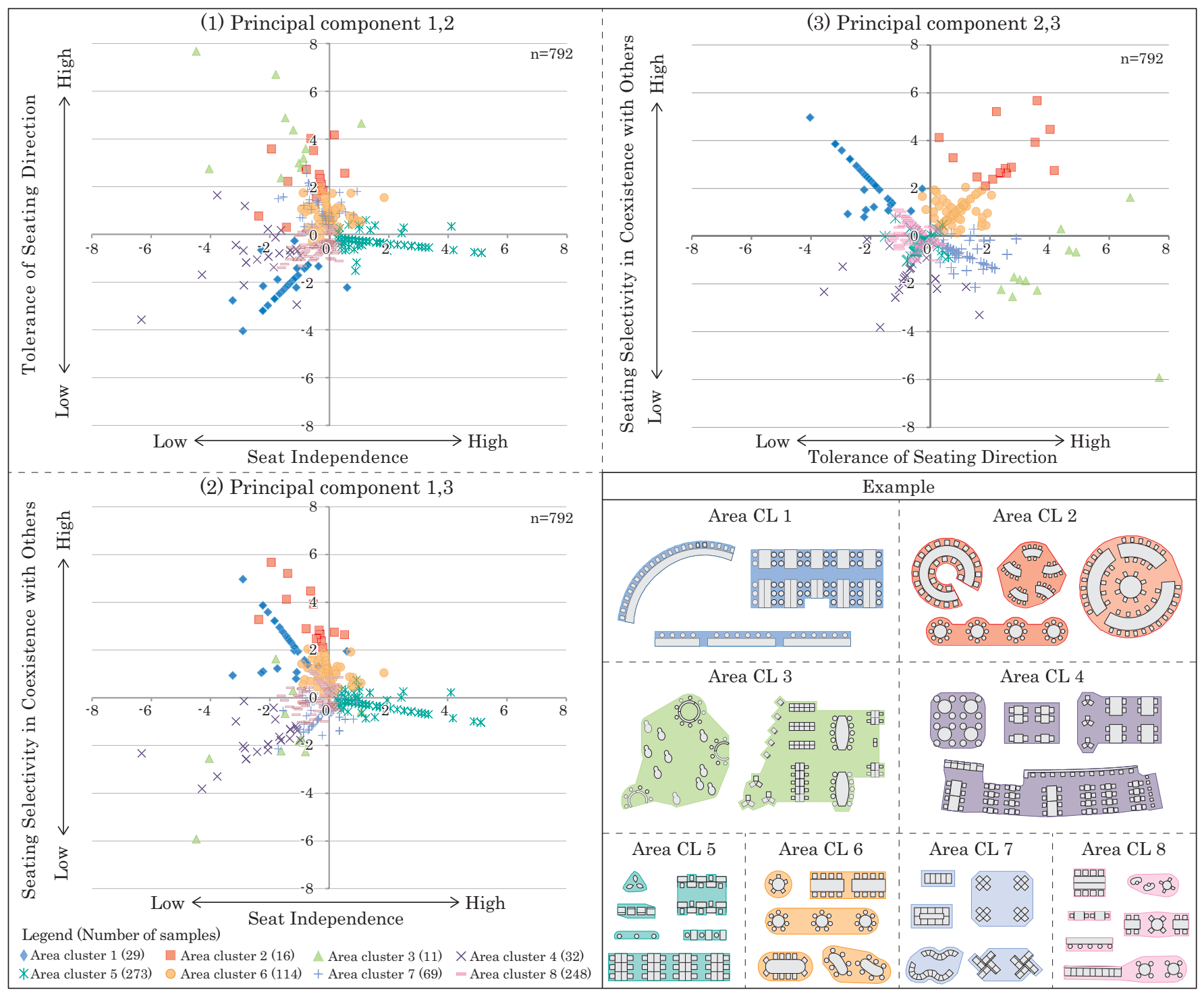

Fig.12 Result of cluster analysis and example of seated areas

既に着座した、もしくは後で着座する他者の存在や影響を考慮した 座席の選びや寸さとも言える。同質な座席が横並びに配置されたサ イド・バイ・サイドの場合、座席の選択性は高いと考えられる。そ れに対し、小規模ソシオペタルのように他者の存在が座席選択に大 きな影響を与えると考えられる座席配置では、座席の選択性が低い

\section{と考えられる。}

\section{5-4. 座席領域の類型化}

各座席領域における 3 つの主成分得点を用いて非階層クラスター 分析 ${ }^{11}$ を行い、8つの領域クラスター（以下、領域 CL) に分類し $た^{\text {注 }}{ }^{12)}$ 。各座席領域における 3 つの主成分得点を用いた、各主成分 の組み合わせによる散布図を Fig. 12 に示す。

その結果として Fig. 12(1) (2)（3）の各領域 CL の分布をみると、 領域 CL1、2、3、4、6、7 は「着座方向の許容度」と「他者との共 在時における座席の選択性」の主成分 $2 、 3$ の意味合いにより特徵 付けることができる。また、Fig. 12（1）（2）の領域 CL5 の分布をみる と、「座席の独立性」という主成分 1 の特徴が表れている。さらに、 Fig. 12(1) (3) の領域 CL8 の分布をみると、「着座方向の許容度」を 表す主成分 2 の值が比較的低く、主成分得点そのものが低い座席領

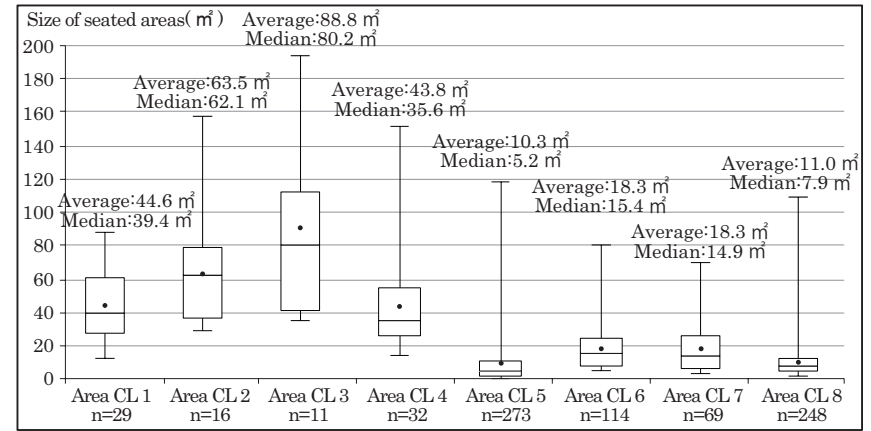

Fig.13 Relationship between area cluster and size of seated areas

域である。

各領域 CL の座席領域例を見ると、領域 CL1 や領域 CL4、領域 CL5 などの座席領域は、同じ座席配置分類かつ同じ形状の家具によって 構成されている座席領域が多く見られるのに対し、領域 CL3 は複数 の座席配置分類の家具で構成されている座席領域が見られる。その 結果、領域 CL3 は主成分 2 の值が高いのに対し、主成分 3 の值にば らつきが見られる。

\section{5-5. 各領域クラスターの座席領域規模}




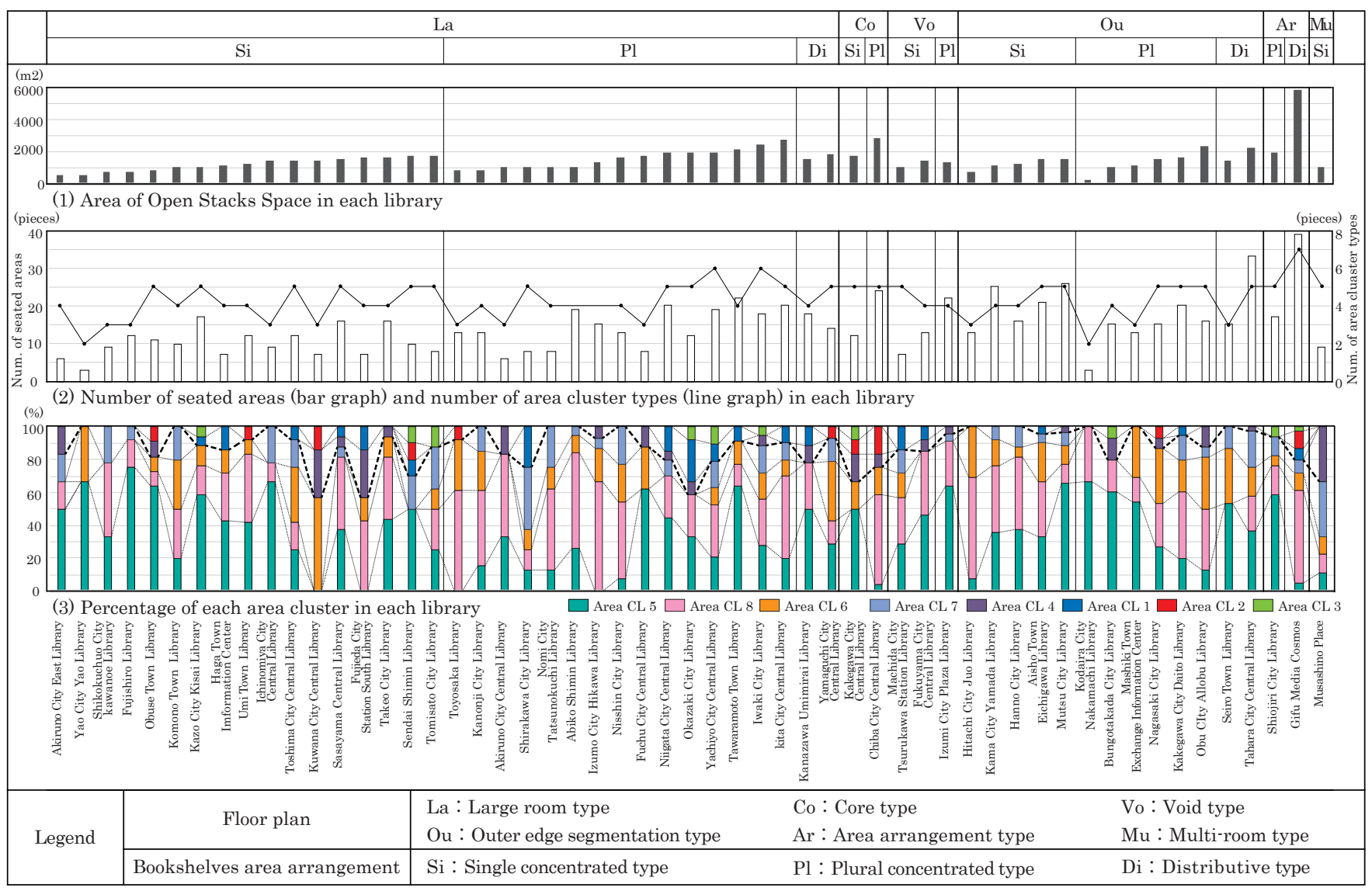

Fig.14 Cross analyses between floor plan types, bookshelves area arrangement types, open reading space area, and area clusters

各領域 CL の座席領域規模をみると、領域 CL1 〜 4 は領域 CL5 〜 8 と比べて領域面積が大きく、有意差 $(\mathrm{p}<0.05)$ も確認することが できた (Fig. 13)。この対比は、各領域 CL 数の多少にも一致してお り、領域 CL 全数 792 の内、 $704(88.9 \%)$ が領域 CL5 〜 8 に該当す る。つまり、分析対象の 55 事例における座席領域は、概ね $20 \mathrm{~m}^{2}$ 程 度以下の座席領域が大半を占めていると言える。領域 CL5 〜 8 の領 域規模を比較すると、領域 CL6 と 7 の平均值がともに 18.3 mであ ったのに対し、座席の独立性が高い領域 CL5 と主成分得点の低い領 域 CL8 のそれは $10.3 \mathrm{~m}^{2} 、 11.0 \mathrm{~m}^{2}$ と相対的に小さく、領域 CL6 およ び 7 と領域 CL5 および 8 の間には、それぞれ有意差 $(\mathrm{p}<0.05)$ が確 認できた。

一方、領域 CL1 〜 4 では、領域 CL3 はその平均值が $88.8 \mathrm{~m}^{2}$ と最 も高く、次いで領域 CL2 が 63.5 m²゙あった。領域 CL3 の面積のば らつきが大きい理由は、事例数が少なく特殊例であること以外に、 様々な座席配置分類の家具で座席領域が形成されている場合や、着 座方向の許容度が高い家具だけで構成されているなど座席周りに比 較的面積的な余裕がある場合が含まれるためと考えられる。

\section{5-6. 各領域クラスターの特徴}

3つの主成分の意味合いや領域規模、領域内座席配置より、各領 域 CL の特徵を以下に示寸。

(1)領域 CL1 は主にサイドバイサイドに分類される家具で構成されて いる。着座方向の許容度が低く、利用者同士も対面しないため、 座席の選択性は比較的高いが、他者との共在感覚は比較的弱く、 利用者のプライベート性が保たれると考えられる。

(2)領域 CL2 は主に大規模ソシオペタルに分類される家具で構成され
ており、着座方向の許容度が高い座席領域である。また、領域内 で共在する人数が他の領域 CL と比べて多いため、様々な着座方 向で利用者同士が向き合い、他の利用者の活動を意識しながら利 用者同士が共在することが可能であると考えられる。

(3)領域 CL3 は大規模ソシオペタルやソシオフーガルに分類される家 具で構成されていることから、領域内で対面する着座方向や相反 する着座方向で共在するため、着座方向の許容度が他の領域 CL よりも高い座席領域である。

(4)領域 CL4 は、 2 人掛け閲覧席や 4 人掛け閲覧席のような小規模ソ シオペタルに分類される家具で構成されており、ある 1 つの家具 における共在感覚は強いと考えられる。しかし、対面する座席が 多いため着座方向の許容度が低く、かつ領域内における家具配置 も一様なため、座席の選択性は低い。よって、領域内で実際に共 在する人数は座席数に対して少ない可能性があると考えられる。

(5)領域 CL5 はキャレル席のようなパーソナルに分類される家具で構 成されており、座席の独立性が高く、他者との共在感覚は弱い座 席領域であると考えられる。

(6)領域 CL6 は領域 CL2 と同様に、主に大規模ソシオペタルに分類さ れる家具で構成されているが、領域 CL2 と比較すると領域規模が 小さく、同時に共在することができる人数は少ない。つまり、着 座方向の許容度は領域 CL2 よりも低い座席領域である。

(7)領域 CL7 は主にソシオフーガルに分類される家具で構成されてい る座席領域である。相反する方向で着座することから、着座方向 の許容度が高く、プライベート性が保たれた状態で共在すること が可能な座席領域であると考えられる。 
(8)領域 CL8 は小規模ソシオペタルやサイドバイサイドに分類される 家具で構成されており、領域内の座席数も他の領域 CL より少な いため、着座方向の許容度が低い座席領域である。

\section{5-7. 領域クラスターと平面型及び書架領域型の相互関係}

最後に、8つの領域 CL と $3 \sim 4$ 章で分析した平面型及び書架領 域型との相互関係について、Fig. 14 を基に分析する。 55 事例の座 席領域数と領域 CL の種類数を示寸 Fig. 14(2) と、各領域 CL の座席 領域数割合を示す Fig. 14(3) では、平面型と書架領域型の組み合わ せ毎に、当該事例の対象開架閲覧空間の面積（Fig. 14(1)）に基づ いて並べられている。

事例数が多い広室型と外縁部分節型の各事例について見ると、 各事例の開架閲覧空間の面積（Fig. 14(1)）と領域 CL の種類数 Fig. 14(2)）の間には、広室型で $r=0.56$ 、外縁部分節型で $r=0.83$ 、 全 55 事例で $\mathrm{r}=0.66$ と相関性がある。実際、広室型の八千代市立と いわき市立は 6 つの領域 CL が確認できるが、開架閲覽空間の面積 も $1978 \mathrm{~m}^{2} 、 2435 \mathrm{~m}^{2}$ と相対的に大きい。

また広室型と外縁部分節型の各事例における領域 CL の構成を見 ると、全 55 事例の傾向と同じく領域 CL5 8 が半数以上を占める (Fig. 14(3) に記載した太点線を参照)。その中でも、独立性の高い 領域 CL5 や着座方向が固定的な領域 CL8 が中心的である。この傾向 を、事例数の多い広室型と外縁部分節型について着目すると、領域 CL5 〜 8 が 90\%を占めるのは、平面型として一般的な広室型で 34 事例中 17 事例であるのに対して、外縁部分節型では 13 事例中 10 事例と違いがある。また、小規模の座席領域が 9 割を超える広室型 の 17 事例と外縁部分節型の 10 事例における、小規模な座席領域の 領域 CL をみると、広室型の 17 事例中 9 事例で領域 CL5 〜 8 の全て の小規模な座席領域が含まれており、外縁部分節型の 10 事例中 7 事例で領域 CL5 〜 8 の全ての小規模な座席領域が含まれていた。こ の結果から、座席領域の小規模化とともに、外縁部分散型では空間 的に分節された外縁部などに小規模かつ様々な特性のある座席領域 が配置されているなど、座席領域と分節された閲覧空間の平面形状 との関係性が読み取れる。

\section{6. 総括}

\section{6-1. 開架閲覧空間における平面構成と座席領域の関係性}

公共図書館の開架閲覧空間の平面構成を 6 つの平面型と 3 つの 書架領域型から整理し、座席領域との関係性を分析した。3つの書 架領域型それぞれの座席領域の合計面積割合の平均值は 15.6\% 17. $6 \%$ であり、有意差は見られなかったが、座席領域数に関しては 単一集中型と他の型の間には有意差が確認された。また、書架領域 型それぞれの書架領域割合を比較すると、書架領域が複数化や分散 化するほど面積割合は減少する傾向にあった。つまり、書架領域の 配置が複雑になると、開架閲覧空間における書架領域の面積割合は 減少する傾向にあるが、書架領域により開架閲覧空間が分節され、 分節された空間に座席領域が形成されるようになるため、座席領域 数は多くなる傾向にあると考えられる。したがって開架閲覧空間の 面積に対して、書架領域が占める割合が小さい場合は、書架による 座席領域の分節がより可能となると考えられる。それに対し、開架 閲覧空間における書架領域が占める割合が大きい場合は、建築的な 要素によって座席領域を分節することになると考えられる。
また、座席領域の形成に対する平面型と書架領域型の影響を分析 した結果、広室型やコア型では書架領域の配置の影響が大きく、外 縁部分節型やヴオイド型、室群型では平面形状の影響が大きい。ま

た、領域配置型では両方の影響が見られた。

\section{6-2. 座席領域の座席配置構成と開架閲覧空間の平面構成の関係}

次に、座席領域内の座席配置に着目して分析し、「座席の独立性」 「着座方向の許容度」「他者との共在時における座席の選択性」の 3 軸によって、全 792 の座席領域を 8 つ領域 CL に分類することが できた。その中で、他の利用者の活動を意識しながら利用者同士が 共在することが可能であると考えられる座席領域や、利用者のプラ イベート性が保たれた状態で他者と共在することが可能であると考 えられる座席領域が確認できた。つまり、本研究の対象事例が竣工 した 2000 ～ 2015 年は滞在型図書館の考え方が共有され、実例が各 地に誕生してきた時期にあたるが、座席空間計画についても滞在型 に応じた計画が実施されている一端が明らかになった。

さらに、前述の座席領域の特性と平面型及び書架領域型の関係を 見ると、事例数の多い広室型と外縁部分節形において、座席領域及 び座席配置の多様化と開架閲覧空間の面積に正の関係性があること が読み取れた。特に外縁部分節型では、開架閲覧空間の外縁部に小 規模の座席領域が形成されており、またその座席配置の特性も多様 である傾向が明らかになった。このように、本研究では一つの平面 型に限られるが、平面形状と座席領域及び座席配置の関係性が確認 できた。

\section{6-3. 本研究の成果と今後の課題}

来館者の滞在や共在の観点から、開架閲覧空間の座席領域と平面 構成について、相互に分析、考察した。多くの利用者にその目的に 応じて効率よく座ってもらう、また形態や寸法、材質等を工夫して 快適に座ってもらうという座席単位の検討だけでなく、本研究で示 した実態に基づく 5 つの座席配置型（パーソナル、サイドバイサイ ド、小規模ソシオペタル、大規模ソシオペタル、ソシオフーガル ) やその組み合わせ（8つの座席領域タイプ）は計画検討上、参考と なる類型となろう。また、55 事例という限られた事例数の分析と いう研究方法上の限界から、知見としては限定的ではあるものの、 座席領域と開架閲覧空間の平面構成に関係性が見られたため、滞在 の観点から閲覧空間を計画するにあたっては、座席領域の小規模化 と分散化とともに、座席配置形態までを含む座席空間計画を閲覧空 間の平面計画において個別的、もしくは従属的に扱うのではなく、 同等かつ双方向に検討する必要性を指摘したい。

一方、本研究では、公共図書館における座席領域に着目し、平面 構成と座席領域の類型の関係性を定量的に分析したが、対象事例が 滞在型を前提にして計画、運営されているか否かまでを確認してい ないため、計画や運営の方針との整合性については検討の余地が残 る。また、どのような座席領域に利用者が居たいと感じるか、また 実際に利用者はどのように利用しているか、といった公共図書館に おける実態との関倸性は明らかにすることはできていない。さらに は、本研究では扱えなかったが、建築と一体化した座席空間も近年 登場してきている。よって、本研究で行った定量的な分析と、多機 能化する公共図書館における最新の実態を、横断的に分析すること で、より詳細な領域構成方法を明らかにすることを研究課題とした い。 
注 1）本研究における「共在」とは利用者同士が同じ空間内で居合わせる状 態のことを指し、「共在状況」とは座席配置によって規定される利用者の 体の向き等の居合わせ方のことを指す。

注 2) 本研究における主要階とはポピュラーライブラリーが配置されている開 架閲覧空間の面積が最も大きな階のことを指す。

注 3） ヴォイド型、コア型は閲覽席の配置という観点からみると、ヴォイド 型はヴオイド周囲に閲覧席を配置することが可能であるのに対し、コア型 は外縁部に閲覽席が配置されている事例が多いことから、異なる平面型と して扱うこととする。

注 4） 55 事例の平面形状を分類する上で、複合的な平面形状が見られる場合 もあるが、本研究では分類できない複合的な平面形状は見られず、対象事 例の主な平面形状により分類した。

注 5）広室型が 34 事例と比較的多くを占めるが、現状の結果であり、他の型 と比較することを重視して、55 事例全てをその後の分析でも用いた。

注 6) 本研究では床が畳敷きの場所や、図面上は認識できないが利用実態と して着座される可能性のある場所については分析対象としていない。

注 7) 以降、有意差の検定は $\mathrm{t}$ 検定による。

注 8)「家具数」とは机の数を家具数とし、机がなく椅子やソファ等のみの場 合は、それ単体で一つと数えている。

注 9)「座席領域を構成する座席家具の種類数」は座席領域内の着座可能人数 及び、机の形状（机がなく椅子やソファ等のみの場合はその形状）で判断 した。

注 10）椅子やソファ等の家具で一人当たりの座席が明示されていないものは、 座席部分の各辺を一人当たりの座席寸法 $(700 \mathrm{~mm})$ で除し、小数点以下を切 り捨てた值を着座可能人数とする。

注 11） Mac 統計解析シリーズ（エスミ）を使用した。

注 12）非階層クラスター分析においてクラスター数を複数指定して検討した 結果、各クラスターの特徵が最も反映されていると考えられたクラスター 数 8 を採用した。

\section{参考文献}

1) Uematsu, S. : Toshokan Shisetsu Ron, Jusonbo Co.Ltd., 2014. 3 (in Japanese) 植松貞夫：図書館施設論，樹村房，2014. 3

2) Nishikawa, K. : History of Library Architecture Development, Maruzen planet, 2010. 11 (in Japanese) 西川馨：図書館建築発展史，丸善プラネット，2010。11

3) Masuko, K. : Design of Library Space, Maruzen, 2018. 1 (in Japanese) 益子一彦：続・図書館空間のデザイン，丸善出版，2018. 1

4) Furuta, D. , Kojima, Y. and Komatsu, H. : Tendency of Spaces and Operation in Japanese Public Libraries from the Viewpoint of Citizens' Multipurpose Uses, Journal of Architecture and Planning (Transactions of AIJ), Vol. 84, No. 759, pp. 1057-1065, 2019.5 (in Japanese) 古田大介，小島悠睴，小松尚：市民の多目的利用の視点からみた全国の 公共図書館の空間と運営の傾向, 日本建築学会計画系論文集, 第 84 巻, 第759号，pp. 1057-1065，2019．5

5) Architectural Institute of Japan : Compact Architecture Design Data Collection Third Edition, Maruzen, 2005. 3 (in Japanese) 日本建築学会：第3版 コンパクト建築設計資料集成，丸善出版，2005．3

6) Wicker, Allan W. : An introduction to ecological psychology, Kyushu University Press, 1994. 7 (in Japanese) アラン・W・ウィッカー, 訳/安藤延男: 生態学的心理学入門, 九州大学 出版会, 1994. 7

7) Shinkenchiku-sha: Shin-Kenchiku, Shinkenchiku-sha Co. Ltd., 2001. 1-2016. 12 (in Japanese) 新建築社：新建築，新建築社，2001. 1 - 2016. 12

8) Kindaikenchiku-sha: Kindai Kenchiku, Kindaikenchiku-sha Co. Ltd., 2000. 1 -2016. 12 (in Japanese) 近代建築社：近代建築，近代建築社，2000．1-2016. 12

9) Kenchiku Shicho Kenkyujo: Data file of architectural design \& detail 97 Library 3, Kenchiku Shicho Kenkyusha, 2004. 7 (in Japanese) 建築思潮研究所： [建築設計資料] 97図書館3，建築資料研究社，2004. 7

10) Eishi, K. : INAX ALBUM 22 Iconography of Library Architecture, INAX, 1994, 4 (in Japanese) 桂英史：INAX ALBUM 22 図書館建築の図像学, INAX, 1994. 4

11) Kitaoka, T. : A Possibility of Planning A Popular Library Area : Studies of the method of zoning an open shelf floor at public libraries (1), Journal of Architecture and Planning (Transactions of AIJ), Vol.73, No. 626, pp. 751-756, 2008. 4 (in Japanese)

北岡敏郎：ポピュラーライブラリーエリア創出の可能性 地域公共図書館 における開架フロアのゾーニング手法に関する研究(1)，日本建築学会計 画系論文集，第 73 巻，第 626 号，pp. 751-756, 2008. 4

12) Kitaoka, T. : The formation of popular library areas and a proposal of it's collections: studies of the method of zoning an open shelf floor at public libraries (2), Journal of Architecture and Planning (Transactions of AIJ), Vol. 74, No. 638, pp. 751-760, 2009. 4 (in Japanese) 北岡敏郎：ポピュラーライブラリーエリアの形成と資料構成案 地域公共 図書館における開架フロアのゾーニング手法に関する研究(2)，日本建築 学会計画系論文集，第 74 巻，第 638 号，pp. 751-760，2009. 4

13) Kitaoka, T. : The Characteristics of the Adult's Uses at the Public Libraries with an Active Zone: Studies of the method of zoning an open shelf floor at public libraries (3), Journal of Architecture and Planning (Transactions of AIJ), Vol. 75, No. 652, pp. 1365-1371, 2010. 6 (in Japanese)

北岡敏郎：Activeゾーンを形成した図書館における成人利用の特徵 地域 公共図書館における開架フロアのゾーニング手法に関する研究 (3), 日本 建築学会計画系論文集，第 75 巻，第 652 号, pp. 1365-1371，2010. 6

14) Kitaoka, T. : The Characteristics of Family Use at a Public Library with an Active Zone: Studies of the method of zoning an open shelf floor at public libraries (4), Journal of Architecture and Planning (Transactions of AIJ), Vol. 76, No. 667, pp. 1545-1552, 2011. 9 (in Japanese) 北岡敏郎：Activeゾーンを形成した図書館におけるファミリー利用の 特徴 地域公共図書館における開架フロアのゾーニング手法に関する研 究 (4), 日本建築学会計画系論文集, 第 76 巻, 第 667 号, pp. 15451552, 2011. 9

15) Nakai, T., Omae, Y. and Imai, S. : Users' Activities and Favorite Place to Stay in Public Libraries A Study on Planning of Library based on Users' Activities Part 1, Summaries of Technical Papers of Annual Meeting, Architectural Institute of Japan, Architectural Planning and Design, pp. 395-396, 2001.7 (in Japanese) 中井孝幸，大前裕樹，今井正次：図書館利用者の館内行為と滞在場所か ら見た居場所の形成 滞在型利用からみた公共図書館の施設計画に関す る研究 その 1 , 日本建築学会大会学術講演梗概集, 建築計画, pp. 395396, 2001. 7

16) Omae,Y., Takayuki, N. and Imai, S. : Factor Analysis to Users' Behavior Making Selection from Places to Stay in Public Libraries A Study on Planning of Library based on Users' Activities Part 2, Summaries of Technical Papers of Annual Meeting, Architectural Institute of Japan, Architectural Planning and Design, pp. 397-398, 2001. 7 (in Japanese)

大前裕樹, 中井孝幸, 今井正次：他者との関係に見る居場所形成の要因 滞在型利用からみた公共図書館の施設計画に関する研究 その 2 , 日本建 築学会大会学術講演梗概集, 建築計画, pp. 397-398, 2001. 7

17) Nakai, T ., Akino, T ., Taniguchi, M. : Activities and Behaviors to Select Seats Based on Users' Generation and Affiliation in Libraries : A Study on the Planning and Design of the Public Librari as a "Place" Part 1, Journal of Architecture and Planning (Transactions of AIJ), Vol. 82, No. 741, pp. 2767-2777, 2017. 11 (in Japanese) 中井孝幸，秋野崇大，谷口桃子：図書館における利用者属性からみた座 席の選択行動と過ごし方「場」としての公共図書館の施設計画に関す る研究 その 1 , 日本建築学会計画系論文集, 第 82 巻, 第 741 号, pp. 2767-2777, 2017. 11

18) Osmond,H: Function as the basis of psychiatric ward design, Mental Hospitals, 23(30), 1957 


\title{
STUDY ON THE RELATIONSHIP BETWEEN SEATED AREA FEATURES AND FLOOR PLAN COMPOSITION OF OPEN READING SPACES IN PUBLIC LIBRARIES IN JAPAN
}

\author{
Yuki KOJIMA ${ }^{* 1}$ and Hisashi KOMATSU*2 \\ ${ }^{*}$ KUME SEKKEI Co. Ltd., M.Arch. \\ * 2 Prof., Graduate School of Environmental Studies, Nagoya Univ., Dr.Eng.
}

This study aims to clarify the features of the seated area compositions in the open reading space of Japanese public libraries. In order to do so, the study analyzes the plans of Japanese libraries completed after 2000 from the viewpoints of floor plan's forms, bookshelves area arrangements, seated areas, and seating arrangements within seated areas.

In Chapter 2, the pertinence of the study is clarified via references to published papers relevant to the study (in context of the aims and methodology already mentioned in Chapter 1).

In Chapter 3, a number of viewpoints are defined. Chapter 4 sees the main floor plans of 55 Japanese libraries completed since 2000 were collected and analyzed - floor plans were sourced from periodicals on architecture and library architecture published until 2016. The results of the analyses are summarized via three points. First, as a result of organizing the samples via six types of floor plans and three types of bookshelves area arrangements, it was confirmed that the size of the open reading space tended to increase as the bookshelves area arrangement became more complicated. When the arrangement of bookshelves became complicated, the number of seated areas tended to increase. In addition, as the size of the library increased, the number of seated areas increased. One of the possible reasons for these results is that bookshelves area arrangement divides the spaces available to form seated areas. Furthermore, the influences on the formation of seated areas differ depending on spatial configuration. Specifically, "large room type" or "core type" are mainly influenced by bookshelves area arrangement; "outer edge section type," "void type" and "room group type" are influenced by spatial configuration; and, "area arrangement type" is influenced by both bookshelves area arrangement and spatial arrangement.

In Chapter 5, all 792 seated areas were categorized by the combination of the concepts of "socio-petal" and "socio-fugal" and the number of seated area; as such, the following three axes could be identified via Principle Component Analysis: (1) "seat independence," (2) "tolerance of seating direction," and (3) "selectivity of seating when living together." Eight seated area types can be found by the analysis based on those axes. In addition, the relationship of eight types of seating arrangements used in seated areas was analyzed in connection with the combination of the types of floor plan and bookshelves area arrangements. The close relationship between the floor area and variety of seating arrangements can be identified; furthermore, it is observed that the four types of seating arrangements which have relatively small areas are more common in "outer edge section types" than in "large room types" (given a comparison between these two types).

In Chapter 6, the findings of this study are discussed. However, this study did not deal with the relationship between seated areas and actual users' behavior in public libraries - such as how actual users use seats and what types of places users recognize as seated areas. Thus, future research may produce for a more detailed composition method for seated areas by overlaying actual users' behaviors onto the results uncovered by this research.

(2021 年 4 月 8 日原稿受理, 2021 年 9 月 28 日採用決定) 